Journal of Teachers of English

Volume 5 No. 2, 2020

e-ISSN: 2548-6810

\title{
THE EFFECT OF MATCH MINE TECHNIQUE ON STUDENTS' SPEAKING SKILL (A Pre-Experimental Study at the Tenth Grade Students of Senior High School 10 Kendari)
}

\author{
Arwa1, Lelly Suhartini, ${ }^{2}$ Muh. Khusnun Muhsin ${ }^{3}$
}

${ }^{1}$ Halu Oleo University, Indonesia.

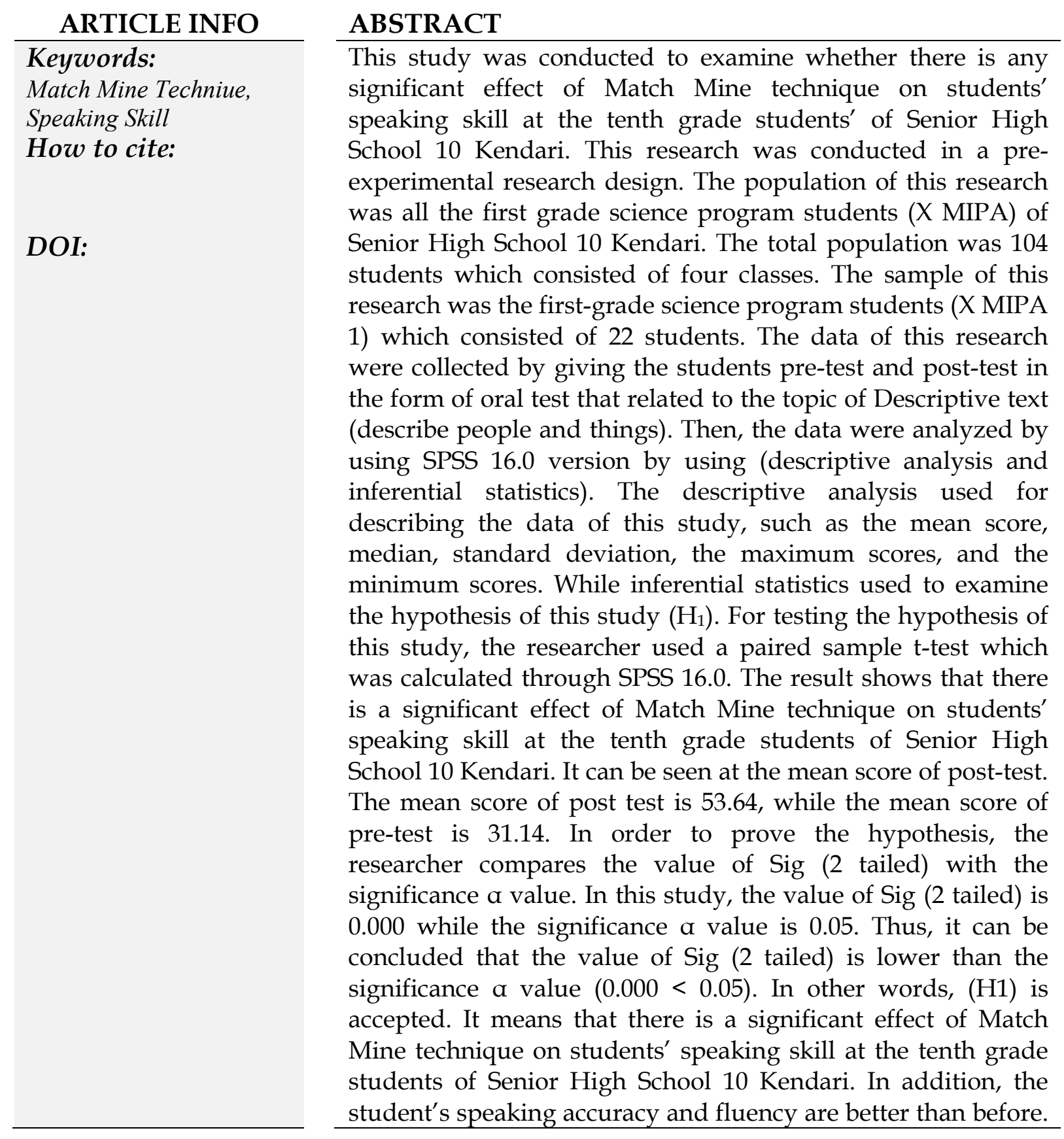


Furthermore, the result of the finding above also shows that Match Mine technique can affect students' motivation and communicative skill and the result of the finding also can be affected by students' intelligence itself.

\section{Introduction}

Speaking is one of the important skills in learning English besides writing, listening and reading skills. Speaking is used to communicate, interact and to express people's feelings, thoughts, opinions and emotions. In addition, speaking is also used to give instructions to others such as to describe things, characteristics of someone, people's behavior, asking about suggestions, etc. However, even though speaking skill is very important, speaking skill is also categorized as one of the most difficult skills in learning English. People must be able to master grammar and vocabulary in aiming to produce this skill very well. Brown, (2003) says that to fluent in speaking, people must be able to master grammar, vocabulary and a bit pronunciation. Therefore, people must be mastering vocabulary and grammar so they will have great speaking skill.

In Indonesia, speaking skill seems more important to be learned by all the students. It is almost needed in every teaching and learning process such as in answering and giving question, discussing and practicing the dialogues. In addition, almost every school in Indonesia requires the students to be able to speak English because they are considered about how important English on students' future for getting better jobs. Some jobs in the world will consider speaking skill to get their employees. The Globalization era is also one of the main keys of how important English especially speaking to be learned by the students in the schools. By globalization era, the students must be able or fluent in communicating by using English. Therefore, they are able or ready to compete with other people from other countries who use English as foreign or second language.

However, based on the observation at Senior High School 10 Kendari, there are some problems faced by the students in learning English especially speaking such as classroom activities, inappropriate teaching techniques, students' anxiety, and ineffective communication. All of the problems above are very affecting students in learning or even in mastering English especially speaking. Therefore, the students of senior High School 10 kendari still find speaking is difficult for them in mastering English.

In order to minimize the problems above, students need to use Match Mine technique in learning and mastering speaking. Match Mine is a very unique technique which can increase the students' speaking skill and can minimize all the problems faced by the students of Senior High School 10 Kendari. Kagan (2009) defines that Match Mine is a learning technique which can help the students to build their communication skill or social skill and can develop the students' ability to 
understand the directions from other friends. Match Mine technique is using oral communication in matching an object with other friends and this technique usually works in pairs.

In conclusion, Match Mine technique is suitable for the students of Senior High School 10 Kendari because Match Mine technique can help students in practicing their speaking skill in a lot of time. Moreover, Match Mine technique can also help the students to improve their communication skills. Coon and Klott (2012) explain that Match Mine is one of the cooperative learning techniques in which the activity is giving and receiving information. It means that the students who use this technique can improve their communication skills. Therefore, Match Mine technique is a cooperative learning technique that is usually used in pairs to communicate with one another.

Based on the identified problems stated previously, the study addressed the following question: "Is there any significant effect of Match Mine technique on students' speaking skill at Senior High School 10 Kendari?”.

\section{Methodology}

This study used a pre-experimental with One-Group Pre-test-Pos-test design to find out the effect of Match Mine technique on students' speaking skill at Senior High School 10 Kendari. This kind of experimental design is just used an experimental group and it does not involve any controlled group. This study was conducted on 9th April 2019 until 3rd May 2019. It was done at Senior High School 10 Kendari. Students of X MIPA 1 class chose to be the sample of this study.

The instrument in this study was referred to any equipment for collecting the data in a research or study. In this study, speaking test (pre-test and post-test) used as the instrument. The researcher gave an oral test to each student by asking them to describe the pictures that the researcher had prepared before.

The data of this study were analyzed quantitatively. The techniques of data analysis in this study were descriptive and inferential statistic. The descriptive statistic used to describe the data of this study such as the mean score, median, standard deviation, the maximum scores, and the minimum scores. While inferential statistics used to test the hypothesis of this study $\left(\mathrm{H}_{1}\right)$. In addition, the researcher used a paired sample t-test to test the hypothesis of this study which was calculated through SPSS 16.0.

\section{Findings and Discussion}




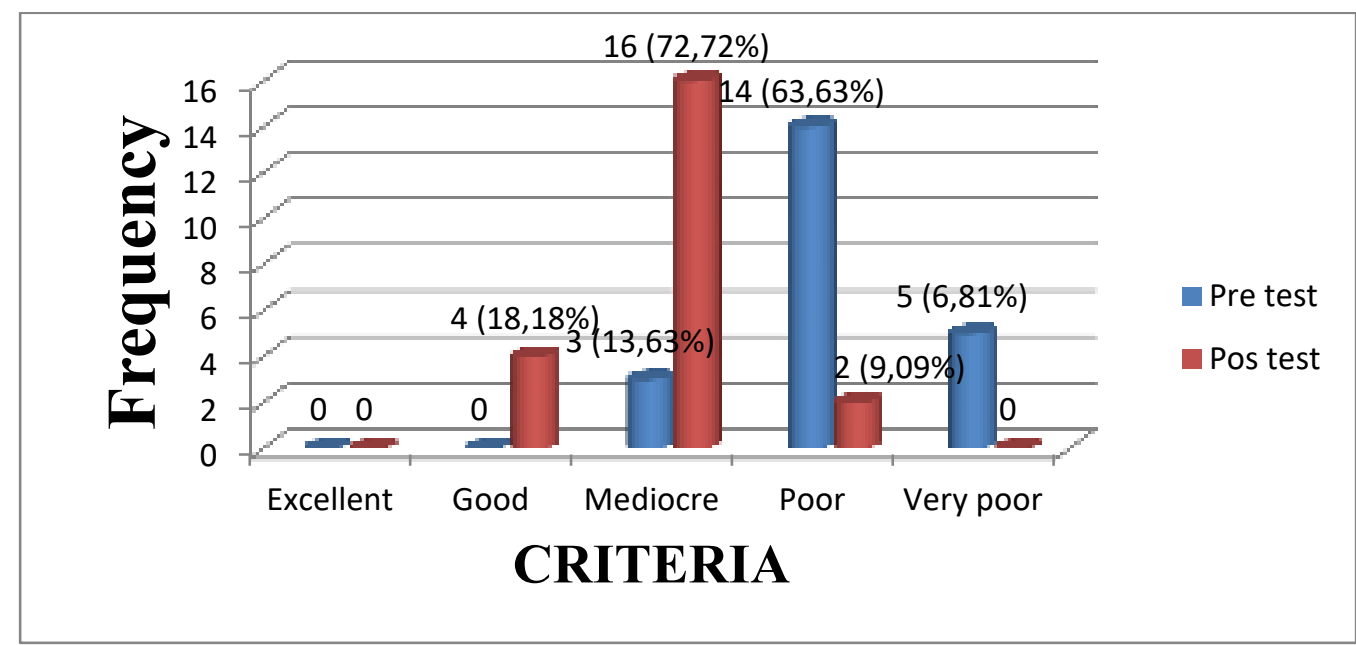

The above graph was about the comparison of the students' classification score both pre-test and post-test. It was described by using the criteria provided by (Harris in Kurniati, Elirwati and Novitri 2015:10). Based on the graph above, there were $5(6,81 \%)$ students who got very poor criteria in the pre-test while in the posttest there were no students who got very poor criteria. Then, 14 students $(63,63 \%)$ who were in poor criteria in the pre-test had increased to the mediocre criteria in the post-test with the total of the students were 16 students $(72,72 \%)$. Relating to the good criteria, in the pre-test there was no student who got good criteria but in the post test, the number of students who got good criteria had increased to 4 students $(18,18 \%)$. In addition, there was no student both in pre-test and post-test who got excellent criteria. Therefore, it can be concluded that the students' speaking skill which was consisted of accuracy (grammar, pronunciation and vocabulary) and fluency in post test were better than in the pre test and it can be predicted that the technique used by the researcher was the key role for making it happened, so the students can be easier in speaking English especially in describing things or people.

Table 4.3 Descriptive statistics on pre test and post test

\begin{tabular}{|c|c|c|c|c|c|}
\hline \multicolumn{1}{|c|}{ Descriptive Statistics } \\
\hline pretest & N & Minimum & Maximum & Mean & Std. Deviation \\
postets & 22 & 20 & 50 & 31.14 & 9.628 \\
Valid N (listwise) & 22 & 40 & 75 & 53.64 & 9.535 \\
\hline
\end{tabular}

Based on the above table, it showed that the standard deviation in pre-test was 9.62 while in pos-test was 9.53. The minimum score in pre-test was 20 while in posttest was 40 . The maximum score in pre-test was 50 while in post-test was 75 . The students' mean score in the pre-test was 31.14 while in post-test were 53.64. So, the result showed that the students' speaking skill who taught by Match Mine technique had a significant difference between pre-test and post-test. 
In this study, the hypothesis testing used to draw the conclusion about whether or not there was a significant effect of Match Mine technique on students' speaking skill at the tenth-grade students of Senior High School 10 Kendari by using t-test with the significant level (0.05). Before testing the hypothesis, the researcher used SPSS 16.0 (Kolmogorov-Smirnov test) in order to test the normality of the data, pretest and post-test. The result of normality test and hypothesis testing can be seen as follows:

Table 4.4 Normality Test

\title{
One-Sample Kolmogorov-Smirnov Test
}

\begin{tabular}{|c|c|c|c|}
\hline & & pretest & Postets \\
\hline$N$ & & 22 & 22 \\
\hline \multirow[t]{2}{*}{ Normal Parameters ${ }^{a}$} & Mean & 31.1364 & 53.6364 \\
\hline & Std. Deviation & 9.62781 & 9.53463 \\
\hline \multirow[t]{3}{*}{ Most Extreme Differences } & Absolute & .238 & 149 \\
\hline & Positive & .238 & .149 \\
\hline & Negative & -.140 & -.092 \\
\hline \multicolumn{2}{|l|}{ Kolmogorov-Smirnov Z } & 1.117 & .697 \\
\hline \multicolumn{2}{|l|}{ Asymp. Sig. (2-tailed) } & .165 & .717 \\
\hline \multicolumn{2}{|l|}{ a. Test distribution is Normal. } & & \\
\hline
\end{tabular}

Based on the output tests of normality Kolmogorov Smirnov above, it can be known that the value of pre-test was 0.165 and post-test was 0.717 . Both values from pre-test and post-test were higher than a value (0.05). The significant value on pretest was 0.165 and it was higher than $0.05(0.165>0.05)$. Then, the significant value on post-test was 0.717 and it was bigger than $0.05(0.717>0.05)$. It means that the data was in a normal distribution. So, it can be concluded that both of data (pre-test and post-test) were normal distribution.

\section{Table 4.5 Paired sample t test}

\author{
Paired Samples Test
}




\begin{tabular}{|c|c|c|c|c|c|c|c|c|}
\hline & \multicolumn{5}{|c|}{ Paired Differences } & \multirow[b]{3}{*}{$\mathrm{t}$} & \multirow[b]{3}{*}{ Df } & \multirow{3}{*}{$\begin{array}{l}\text { Sig. }(2- \\
\text { tailed) }\end{array}$} \\
\hline & \multirow[b]{2}{*}{ Mean } & \multirow{2}{*}{$\begin{array}{c}\text { Std. } \\
\text { Deviation }\end{array}$} & \multirow{2}{*}{$\begin{array}{l}\text { Std. Error } \\
\text { Mean }\end{array}$} & \multicolumn{2}{|c|}{$\begin{array}{l}95 \% \text { Confidence } \\
\text { Interval of the } \\
\text { Difference }\end{array}$} & & & \\
\hline & & & & Lower & Upper & & & \\
\hline $\begin{array}{ll}\text { Pair } & \text { pretest - } \\
1 & \text { postets }\end{array}$ & $\begin{array}{r}- \\
2.2500 \\
0 \mathrm{E} 1\end{array}$ & 4.81812 & 1.02723 & -24.63623 & -20.36377 & -2.1904 & 21 & .000 \\
\hline
\end{tabular}

Based on the result of paired sample t-test above, it showed that a significant differences exist in the students' pre- and post-test scores, $t(21)=-2,1094, \mathrm{p}(0.000)<$ 0.05 , in that table, post-test scores $(M=53,64 \mathrm{SD}=9,53)$ are significantly higher than pre-test scores $(M=31,14, S D=9,62)$ - a significant gain of 2,25 points. Therefore, it may be said that Match Mine technique has a significant effect on students' speaking skill at the tenth grade students of Senior High School 10 Kendari. In other words, H1 was accepted.

In addition to conclude the hypothesis based on the comparison between the value of Sig (2 tailed) with a value, the researcher also took the conclusion of hypothesis by comparing between value of test with ttable. Based on the calculation of the pre-test and post-test above, it found that the standard deviation was 4,81 . While the mean difference between post-test and pre-test was 2,25. Therefore, it used t-test formula as follows:

$t=\frac{D}{S D / \sqrt{n}}$

$\mathrm{D}=$ The mean difference between post test and pre test

$\mathrm{SD}=$ Standar deviation from $\mathrm{D}$

$\mathrm{N}=$ Total sample

Which calculated, as follows:

$t=\frac{2,25}{4,81 / \sqrt{21}}$

$t=\frac{2,25}{1,04}$

$t=2.163$

Table 4.6 Summary of Hypothesis Testing

\begin{tabular}{|c|c|}
\hline Statistics & \\
\hline
\end{tabular}

Arwa: The Efffect of Match Mine Technique on Students' Speaking Skill (A Pre-Experimental Study at the Tenth Grade Students of Senior High School 10 Kendari) 


\begin{tabular}{|c|c|c|c|c|}
\hline $\mathrm{Df}=(\mathrm{n}-1)$ & A Value & $\mathrm{t}_{\text {test }}$ & $\mathrm{t}_{\text {table }}$ & Result \\
\hline$=22-1$ & 0.05 & 2.163 & 2.080 & $\begin{array}{c}\mathrm{H}_{1} \text { is } \\
\text { accepted }\end{array}$ \\
\hline
\end{tabular}

Based on table 4.5 above, it can be concluded that the value of test (2.163) is bigger than the value of table (2.080). It means that $\mathrm{H}_{1}$ was accepted. In other words, there was a significant effect of Match Mine technique on students' speaking skill at the tenth grade students of Senior High School 10 Kendari.

Furthermore, Match Mine technique also can improve several things such as students' motivation, communicative skill, and speaking fluency and accuracy. The first is students' motivation. When implementing this technique, the researcher found that students' motivation was improved when they learned it by using Match Mine technique. It happened because this technique allowed the students to practice their speaking skill or ability a lot. Slavin (1980) states that the focused of Match Mine technique is to involve the students to be active in learning process. In Mach Mine technique, students spend much time in practicing their speaking than focused in learning material. Therefore, students' motivation is increased.

The second is Match Mine technique enhances students' communicative skill. Match Mine technique can develop students' communicative skill and that is the key point why it is different from the conventional technique. The difference between Match Mine technique and conventional or traditional technique is traditional technique discourages student interaction and set up a competitive environment. While the students who learned by using Match Mine technique are mostly provided each other greater social support (Johnson \& Johnson, 1985). In Match Mine activities, students are trained to be more active in doing an interaction with other students by using English and they are worked cooperatively by divided them into pairs. In this technique, interaction is fostered at all levels. Therefore, the students' communicative skill may enhance.

The last, Match Mine technique can improve students' fluency and accuracy in speaking. Match Mine technique is a technique that involved a pair work activity. It means that there will be two students who will interact to each other when this technique is applied. To describe how Match Mine technique improves accuracy in speaking, it is essential to mention how the benefits of Match Mine in contributing to the improvement in terms of vocabulary, pronunciation, and grammar in speaking. Match Mine technique requires the students to interact and share the information by describing the pictures. In this technique, the students were divided into pairs and they listened to the description of their friends. In the implementation of this technique, the teacher decided one student as sender and other as receiver. When the 
sender described or gave the information about the picture, the receiver heard it and observed it carefully so the receiver drew the same picture as what the sender had been described. After this step had been done so the students tried to match the pictures together and discuss about the description of the sender given before. Thus, they checked the accuracy, in this case pronunciation, grammar, and vocabulary

In addition, Match Mine technique also improves students' fluency. It happened because this technique gave opportunities to the students to be active in speaking. This technique also asked the students to work in pairs. Therefore, they were often done communication in English with their friends. McDonough and Shawn (1993) say that pair wok requires the students to be active in most classrooms activities. They had enough time and opportunity to interact together with the person sitting next to them and they had less interaction with the teacher. Therefore, students were active because they did not learn alone, but they learned together with their friends. They had partners to communicate. Furthermore, one way to improve the fluency of students in speaking skill is by giving a time limit to students in speaking. According to Harmer (2013) "a pair work activity can increase the amount of speaking time any student gets in the class". So, the researcher gave limited times to the students in describing the pictures to their friends. The students were given 57 minutes to describe the pictures. Then, they switched the role so the students had the same chance to speak.

\section{Conclusion and Recommendation}

Based on the result of the data analysis on chapter IV, the researcher concluded that there is a significant effect of Match Mine technique on students' speaking skill at the tenth grade students of Senior High School 10 Kendari. The result of data analysis showed that students' mean scores from pre-test were higher than post-test. The students' mean score in pre test were 31.14 while in the post test were 53.64 .

In this case, the result also showed that $\mathrm{H}_{1}$ is accepted. It can be seen from the different result of the value of Sig ( 2 tailed) from the significance a value. The value of Sig ( 2 tailed) was lower than the significance a value, $\mathrm{p}(0.000)<0.05$. Therefore, Match Mine technique has a significant effect on students' speaking skill and it can be said that Match Mine technique is an appropriate teaching technique for improving students' speaking skill.

In addition, Match Mine technique also improves students' fluency and accuracy. It was happened because Match Mine technique focused on how to communicate with each other in the right way. Match Mine technique made the students to be in pair and it was required the students to be active in speaking. In other words, Match Mine technique gave the students opportunities to speak 
fluently and accuracy in the classroom so their pairs understood about the description of their friends. Besides, the implementation of Match Mine technique on students' speaking skill affects motivation and communicative skill, on students at the tenth grade students of Senior High School 10 kendari.

1. For Teachers

For the success of teaching English, the teacher must be able to make the students talk a lot in English. Match Mine technique is an alternative technique that can be used by the teacher in teaching speaking. It gives a chance to all students to be active in speaking English. This technique also can build students' communication skill so they will be easy to speak English with other people. Besides, in carrying out this technique in the classroom, the teacher must control the students in order the students are involved in practicing their speaking skill.

2. For Students

For the success of learning process, students need to be more active in the classroom. Especially in learning speaking, students must be more active in practicing their speaking skill. It means that students must be able to express their feelings, thoughts and ideas orally. Besides, in practicing their speaking skill, students should not feel afraid. They just need to practice their speaking skill as much as possible.

3. For the Further Researcher

After conducting this study, the researcher recommends that the further researchers can conduct the research about Match Mine technique through other skills, not only in speaking skill. In addition, they can use different kind of research methods in conducting the research about Match Mine technique such as quasiexperimental design or classroom action research (CAR).

\section{References}

Amrullah, A.Z. (2015). Developing Language Games to Teach Speaking Skill for Indonesian Senior High School Learners. Gresik. Published Journal . 20-31. 
Brown, H. D. (2003). Teaching by Principle and Interactive Approach to language pedagogy. New York: Longman Inc.

Celce-Murcia. M.(2001). Teaching English as a Second or Foreign Language (3rd ed). Boston USA: Heinle\&Heinle.

Davies, P., \& Pearse, E. (1998). Succes in English Teaching. Oxford University Press.

Harmer, J. (2013). How to teach English (second edition): An Introduction to the Practice of Language Teaching: How to describe learning and teaching. London: Longman Group UK Limited.

Johnson, D. W. \& Johson, R. T. (1985). The Internal Dynamics of cooperative learning groupsm In: Learning to Cooperate, Cooperating to learn, R. Slavin, S. Sharan, S. Kagan. R. Lazarowitz, C. Webb, and R. Schmuck Eds. Plennium Press, New York.

Kagan, Spencer., and Miguel Kagan. (2009). Kagan Cooperative Learning. San Clamente: Kagan Publishing.

Kusrina, E. (2012). Teaching Speaking for Senior High School Students Using Cooperative Learning "Think Pair Share". Purwokerto: Muhammadiyah University of Purwokerto. Published Journal. Volume. 2. Number 2. 13-33.

Latifah. (2011). Pengaruh Pembelajaran Kooperatif Tipe Match Mine Terhadap Kemampuan komunikasi Matematika Siswa.

McDonough, J. \& Shaw, C. (1993). Materials and methods in ELT. Blackwell.

Slavin, R. E. (1980). Cooperative Learning. Review of Educational Research.

Scott, Thornbury. (2005). How to Teach Speaking. New York: Longman.

Slattery, M., \& Willis, J. (2001). English for primary teachers: A handbook of activities and classroom language (Vol. 1): Oxford University Press. 